\title{
The Kinds of the Linguistic Interference
}

\author{
Sayana Movsum Baghirova \\ Azerbaijan University of Languages, Azerbaijan
}

\begin{abstract}
In the scientific literature, the symbols L1 (Language 1) and L2 (Language 2) are used to indicate the sequence of languages. In most countries, $L 1$ is understood as a first language, and it usually coincides with the mother tongue. The other languages are learned later. This can be seen in the children of multilingual parents. Teaching a second foreign language covers everything a student hears and sees in a new language. This includes a variety of discourse activities, such as exchanges in restaurants and shops, talking to friends, reading billboards and newspapers, as well as teacher-student attitudes in the classroom, as well as language activities and books in the classroom. Regardless of the learning environment, the learner's goal is to master a target language. The learner starts the task of learning a second language from scratch (or close to it) and uses the necessary language skills in the mother tongue to determine the reciprocity of language units in the target language.
\end{abstract}

Index Terms - foreign, language, target, transfer, negative, positive, interference

\section{INTRODUCTION}

To understand the concept of language or linguistic interference, it is first necessary to understand the concept of "transfer". Language or linguistic interference is often perceived as a transfer [Gass and Selinker 1983, p. 11].

As it is well known, interference involves the avoidance of an individual's speech in the other language as a result of the influence of the mother tongue on the language spoken at all levels. Interference can be considered to be both negative and positive. Negative transfer reflects the difficulties encountered in the use of the target language. This difficulty occurs mainly when the target language is used in conjunction with the other language. Positive transfer means facilitating language learning. In this case, the similarity between Language 1 and Language 2 comes to the forward [Kellerman 1987, p. 13]. Thus, language or linguistic interference is considered to be the transfer of the mother tongue to the target language.

For example, when speaking in English, the fact that Azerbaijanis pronounce dorsal rather than apical pronouns is a clear example. In the Azerbaijani language, the consonants are dorsal, for instance, these consonants are formed on the back of the tongue. In English, these consonants are characterized by the activity of the tip of the tongue [Veysalli 2015, p. 85]. As mentioned, there are two types of interference: positive and negative [Odlin 2001, p. 56]. The greater the difference between the mother tongue and the target language, the greater the negative interference is possible to be used by the speakers. The examples given in English and in Spanish can illustrate the facts that are wanted to be explained to. As it is known, the preposition /on/ is used before the names of the week. For example: /He is going to the beach on Sunday// (O, bazar günü çimərliyə gedir). In Spanish, the definite article is used instead of the preposition /on/. The example: /Se va a la playa el domingo// Observations show that inexperienced Spanish students who speak English as their mother tongue can make a transfer mistake using a word when it is not necessary, because they are accustomed to using the preposition /on/ in English. According to E. Kellerman, it is natural for second-language students to make such a mistake. A negative transfer can also be found in the speech of German students studying English [Kellerman 1987, p.11]. For example, the word /məlumat/ in German (/information/ in English) is written as /informationen/. German students often use the negative transfer of "informations" in English, which is almost always the wrong option. Considering the issue in a more general way, J. Askedal writes that all new learning methods usually involve transfer based on the previous learning [Askedal 1994, p.219].

M. Barnes and the others write that it is often not easy to observe because a positive transfer occurs mainly among similar language units, and therefore it is not much discussed about [Barnes 1999, 190]. However, they can also affect the language studied by. In general, the closer the two languages are to each other, the more positive the transfer is possible to be noticed. For example, an English learner can easily guess any word in German, but of course, when composing any sentence, obvious differences in word order and meanings will be inevitable. Language interference is analyzed from different perspectives. L. Beebe writes that in a limited sense, language intervention combines the tendency of the learner to translate the rules of the native language into a foreign language - it can be a second or third language [Beebe 1977, p.231]. In addition, from a psycholinguistic point of view, language intervention is defined as the negative transfer of language skills and abilities from a mother tongue to a foreign language [Beebe 1980, p. 433].

\section{DISCUSSION}

From a linguistic point of view, negative transfer is divided into several types: a) lexical negative transfer, b) syntactic negative transfer, 3 ) chinglish expressions. 


\section{Negative Transfer Observed in the Lexical Layer}

The morphemes of a language communicate both separately and as part of larger language units, i.e. lexemes. In traditional linguistics, words are grouped: the noun, the adjective, the numeral, and so on. This grouping is carried out on the basis of certain characteristics. F.Veysalli writes that the correspondence of a fixed meaning to each form is the main categorical feature of each word [Veysalli, 2013, p.139]. Students who learn a foreign language, especially English as a second foreign language, can make lexical negative transfers by making mistakes in any part of speech. In addition, English is known for its extensive pronoun system. These include: person pronouns, possessive pronouns, reflexive pronouns, reciprocal pronouns, indefinite pronouns, interrogative pronouns, relative pronouns and conjunctive pronouns [Wei 1998, p. 11]. Even when using pronouns, it is possible to observe a lexical negative transfer in the speech or writing of students learning a foreign language.

\section{ANALYSES}

Most sentences in English consist of a subject and a predicate. The role of the message in the grammatically correct organization of the sentence is great, and the incorrect use of the predicate or mistakes in the predicate can change the basis of the sentence, and the interference is considered to be observed as lexically negative transfer. Therefore, the predicate is considered to be an indispensable part of the sentence in English.

Lexical transfer is mainly observed in words. It is known that a word is a semantic unit and each word has a specific meaning of its own. A word that is not used in the right sense can lead to misunderstandings. In addition, the word must be pronounced correctly. F. Veysalli considers a word as a phonetically formed whole and claims that it has a single stress [Veysalli 2013, p.142]. Linguists claim that the word can be used separately from other units [Veysalli 2013, p.142]. When determining the meaning of a word, attention is first paid to the semantic criterion as a word is considered to be a unit of language that has a meaning alone [Veysalli 2013, p.142]. F. Veysalli has interesting ideas about the meaning of the word. According to this scholar, a word may have more meaning than one. For example, in the Azerbaijani language, the word "çəkmək" can have several meanings: 1) smoking; 2) pull the cart; 3) to be ashamed and so on. In German, the words /Weib/, /Frau/, /Junge/ refer to a woman, but in the first case it is an archaic word and in general it means a woman, in the second case it means a specific woman or a husband. The third word refers to a very young woman. Bedouins have many words to describe different types of camels. It is impossible to give them in one word in the other language [Veysalli 2003, p. 90]. On the other hand, in English, the words /sit down/ (oturmaq) and /stand up/ (ayağa durmaq) have a different meaning, and within a phraseological combination they can have a completely different meaning. In general, it is impossible to derive phraseological combinations or idioms from separate components. Therefore, taking into account all these situations, it should not be surprising that there are lexical transfers in the language - in writing, speech, and their negative aspects for language learners. Note that in the linguistic literature, negative transfers are called 'false friends' [Bengeleil et al, 2004, p.225]. We wanted to give an example of lexical negative transfer from Norwegian. From time to time, Norwegians also face 'false friends'. For example, in both English and Norwegian, the word /time/ has the same meaning in the written form. However, in Norwegian, the word /time/ does not mean /time/, but only /hour/ or the infinitive/to/ in English, or the preposition/to/ and in Norwegian the numeral /to/. These lexical units can be confusing for Norwegian students learning English [Askedal 1994, p.219]. It is noteworthy to mention that although Russian and English belong to different language families, these 'false friends' can be found in these languages as well. For example, the pronunciation of the word /аккуратный / (akkuratnyi) (səliqəli; nizaml1) in Russian is similar to the pronunciation of the word /accurate/ in the English language. However, both words have completely different meanings [Andrews et al, 1997, p. 34]. Here the phonetic side of the words comes to the fore. Each word is considered to be a phonetic whole. There are languages (for example, Turkic languages) in which the emphasis always falls on the same syllable [Veysalli 2013, p.143]. So in such languages, emphasis is on words. In Czech, the emphasis is always on the first syllable, in Polish on the first syllable, and in Azerbaijani on the last syllable. The difference in emphasis is more pronounced in British and American English.

In most cases, the difference in emphasis between the British and the American variants is found in words with two, three, four and five syllables, and the emphasis in the word is of interest with the division of the first degree accent [Beebe 1980, p. 433].

$\begin{array}{ll}\text { British version } & \begin{array}{l}\text { American version } \\ \text { tri' bune (tribuna, kürsü) } \\ \text { 'Tribune }\end{array} \\ \text { 'Plateau } & \text { pla' teau (yayla) }\end{array}$

In two-syllable verbs ending in the particle /ate/, the first-order stress falls on the first syllable in the American variant and on the second syllable in the British variant. For example:

\section{British version}

Dic' tate

Fru' strate

\section{American version}

'dictate (diktə etmək)

'frustrate (alt-üst etmək, pozmaq)

In three-syllable words, the first syllable is the second syllable in the American version and the first syllable in the British version. For example:

American version

Com' posite
American version

'composite (birləşdirilmiş, qarışıq) 
In five-syllable words, the first syllable is the third syllable in the American version and the first syllable in the British version. For example:

Custo' marily

Momen' tarily

'Customarily (adətən)

'Momentarily (anidən, ani)

In addition, F. Veysalli writes that the suffix attached to the root of the word also emphasizes it in four variants or in two variants [Veysalli 2013, p.143]. Let's compare: $o c a q+c ̧ ı, \ddot{u} z \ddot{u} m+c ̧ \ddot{u}$, əkin $+c i$ and so on. According to the opinion of this scientist, the combination of a synsematic word with an autosemantic word is usually called a phonetic word [Veysalli 2013, p.143]. For example, in German "auf dem Tisch", in English "on the table", in Russian "на столе" (stolun üzərində) [Barnes et al, 1999, p.190]. The unstressed element is consideredto be proclitic when it comes before the accent, and enclitic when it comes later. Let's compare: /Zu der Schule/ (məktəbə); /in the room/ (otaqda), "ihm zufolge/ (ona görə).

If the word in German is complex, the strong emphasis falls on the first component, and the weak on the second component. For example: "bdunkelblau" (tünd mavi), "steinreich" (çoxlu daşlıqlı), but "steinreich" (çox varlı). It is known that in English and German it is not easy to distinguish words and phrases by emphasis. Let's compare: /'blackbird/ (qara quş), /black’board/ (qara lövhə) so on.

S. Gass et al. write that grammatical limitations can lead to both positive and negative transfers [Gass and Selinker 1983, p.83]. If the grammatical restrictions are the same in both languages, then the transfer is easier. Thus, grammatical restrictions in English but not in Norwegian or Russian can make it difficult to learn English. For example, the English verb / to feel / is considered reflexive in both Norwegian and Russian: / å føle seg / in Norwegian; and in Russian / чувствовать себя / (chuvstvovat sebya) [Evtyukhin 2003, p. 90]. Thus, students can make a negative lexical transfer by applying a reflexive form in English.

T. Odlin writes that if we compare Norwegian and English, then it is necessary to pay attention to non-free morphemes. For example, the prefix / -un / in English and the prefix /-u/ in Norwegian are often lexically negative. Thus, most Norwegian students use the /-u/ prefix instead of the /-un/ prefix. For example, it is used in English as /unreliable/, and in Norwegian as /upålitelig/ (invalid) [Odlin 2001, p.82]. However, it should be noted that non-free morphemes often do not coincide with the same suffix in both languages. For example, the Norwegian prefix /-u/ is often used differently from the English prefix /-un/. For example, it is used in Norwegian as /umulig/ (qeyri-mümkün) and in English as / impossible / (qeyri-mümkün). However, similar signs can make it easier to read and listen to prefixes in English and Norwegian, and in many cases can help readers identify words as relatives.

However, the advantage of general vocabulary allows many language users to understand and read English more easily. However, it should be noted that the reason why English is easy to learn for many foreign language learners is not only due to lexical similarity and pronunciation. For example, suppose that Russian and English have different alphabets. One uses the Cyrillic alphabet and the other the Latin alphabet. When Russian-speaking students learn English, they initially tend to spell words differently. Of course, those with the same writing system, or those with a closer writing system, find it easier to write in English than in languages with different alphabetic systems. For this reason, researchers are now trying to find out which requirements are preferred or difficult for language learners.

2. Negative Transfer in Syntax

In this way, we would like to draw your attention to the comparison of the Azerbaijani and English languages. As it is known, English and Azerbaijani languages belong to different language families, so they differ from each other both in terms of grammatical structure and in terms of the language family to which they belong.

Syntax plays a major role in the language system. The term syntax includes two meanings, two areas that differ from each other and are based on the same source. Many people now agree that it is important to use sentences correctly in order to communicate successfully, and that sentences are the main linguistic unit in a language. The syntax-level transfer is mainly reflected in the semantic differences between the native language and the target language. In this case, syntactic transfer is determined on the basis of three factors: 1) grammatical factors; 2) rhetorical factors; 3) idiomatic factors.

A. Huseynov writes that in English, the syntactic relationship between the members of a sentence is mainly expressed through the word order, so the word order has a syntactic function in the language [Huseynov 2015, p.359]. At the same time, it should be noted that when the place of completeness with the principle changes, along with the syntactic meaning of the members of this sentence, the general semantics of the sentence also changes. These two situations occur simultaneously. This is an indication that the word order has a syntactic-semantic function. For example: /Tom sees Nick// (Tom Niki görür); /Nick sees Tom// (Nik Tomu görür).

As can be seen, when the order of words changes, both the meaning of the sentence changes and the principle and completeness replace each other.

Syntactic transfer is widely observed in the study of languages, and at the same time it is a very controversial issue. T. Odlin also believes that this issue is controversial [Odlin 2001, p.85]. As it is known, in most languages the word order is formed mainly in the form of VSO (predicate, subject, object), SVO (subject, predicate, object) or SOV (subject, object, predicate).

As mentioned above, the word order in modern English is quite stable. The degree of stability or freedom of a word sequence in a sentence depends on the grammatical, or rather morphological, structure of the language. In general, the 
richer the morphological structure of a language, the freer the word order. For example, in modern Russian. The weaker and poorer the morphological structure of a language, the more stable the word order of that language (as in modern English). If we compare the word order of Russian and English, then it is appropriate to give an example of the negative syntactic transfer that occurs in them. In both languages, word order is usually based on the SVO (subject, predicate, object) sequence. However, as we have noted, they differ in terms of freedom. T. Odlin writes that the freedom of words in the Russian language depends on the predominance of non-free morphemes in them [Odlin 2001, p.86]. In the Russian language, nouns have word endings, and this fact allows a reader or a listener to determine whether the noun plays the role of indirect completeness, or as a function of the sentence [Odlin 2003, p.87].

Let us analyse the following examples:

1) /Коля купил машину// (Kolya Bought the car) (word order SVO) (Kolya avtomobil ald1).

2) /Коля машину купил// (Kolya BOUGHT the car) (word order SOV) (Kolya avtomobil ALDI).

3) /Купил Коля машину// (Kolya did bought the car) (word order VSO) (Kolya da avtomobil ald1).

4) /Купил машину Коля// ( KOLYA bought the car) (word order VOS) (KOLYA avtomobil aldı).

5) /Машину Коля купил// (The car, Kolya BOUGHT it) (word order OSV) (Avtomobili Kolya ALDI).

6) /Машину купил Коля// (The car, it was Kolya who bought it) (word order O V S) [Odlin 2001, s. 86].

As can be seen from the examples, the word /машина/ used in the Russian language is used in the form /машину/, which shows that the noun used in the sentence acts as an indirect complement [Odlin 2003, p.87]. This allows Englishspeaking students to use some sentences in several variants, even though the word order in English is stable.

As mentioned above, words exist in all natural languages and have a form and a meaning. K.Sajavaara writes, "All natural languages have sentences, and those sentences have forms and meanings; the meaning of a sentence is determined by the meanings of the words used in the sentence" [Sajavaara 1986, p.86]. None of these assumptions are controversial. Each of them sounds right. The meaning of a sentence is clarified not only by the meaning of the words that make it up, but also by its grammatical structure. It is possible that two sentences of the same word have different meanings according to the grammatical rules used. Let's give an example:

He is reading now. (O, indi oxuyur)

Is he reading now? $(\mathrm{O}$, indi oxuyur?)

The first sentence is a declarative sentence and the second is an interrogative sentence. The grammatical difference between them is reflected in the corresponding grammatical structure they reflect.

The other example:

/Harry admires Meghan// (Harri Meqana heyrandir).

/Meghan admires Harry// (Meqan Harriyə heyrandır).

Although both of these sentences are metaphorical, there are still differences in form and meaning between them. K. Sajavaara called this difference as a word meaning and a sentence meaning [Sajavaara 1986, p.32].

One of the areas where negative transfers are observed in the syntax of the English language is the use of phraseological verbs in the English language. English phraseological verbs are considered to be one of the most difficult areas for learners of English as a second foreign language. Phraseological verbs are known as one of the areas that contain the most characteristic features of the English language. In 1712, M. Mattaire in his book "Grammar of the English language" conducted extensive research on the main syntactic features of English phraseological verbs. Later, in 1755, the well-known lexicographer S.Johnson wrote, focusing on English phraseological verbs: "Phraseological verbs should be studied carefully, because they are the broadest and most important field that reflects the specific features of each language [Thim 2012, p.1].

Let us consider some phraseological verbs that have several different meanings: /to come off/ to escape by a fetch (qaçıb canını qurtarmaq); /to fall on/ to attack (hücüm etmək); /to fall off/ to apostatize (mürtəd etmək); /to break off/ to stop abruptly (qəfildən dayanmaq); /to bear out/ to justify (haqq qazandırmaq); /to fall in/ to comply (riayət etmək); /to give over/ to cease (dayanmaq; dayandırmaq); /to set off/ to begin a continual tenour (davamli bir işə başlamaq); /to set out/ to begin a course or journey (səyahətə başlamaq); /to take off/ to copy (surətini ç1xarmaq) and so on. The usage of these phraseological verbs in the language is very difficult for learners of English. We have compiled a list of some of the most frequently used phraseological verbs in English and American English: /check out/ (yoxlamaq), /come out/ (görünmək; göz qabağına çıxmaq), /come up/ (yaxınlaşmaq), /figure out/ (bir şeyi başa dümək; anlamaq), /get out/ (tərk etmək), /go ahead/ (qabağa getmək), /grow up/ (böyümək), /hang out/ (bir kəslə vaxt keçirmək), /hold up/ (güclü olmaq; güclü qalmaq), /lay out/ (bir şeyi yaymaq), /pick up/ (qaldırmaq), /pull out/ (bir işdən geri çəkilmək), /show up/ (görünmək; peyda olmaq), /shut down/ (yavaşımaq; bir işi dayandırmaq), /take off/ (qalxmaq; uçmaq; yola düşmək), /end up/ (bir yerdə olmaq), /turn out/ (müəyyən olmaq; baş vermək), /take on/ (icra etməyə başlamaq; bir işə cəlb etmək), /turn around/ (yaxşılığa doğru dəyişmək), /wake up/ (oyanmaq), /build up/ (qurmaq; tikmək; gücləndirmək), /carry on/ (yerinə yeirmək), /fill in/ (doldurmaq; tamamlamaq), /get on/ (yola getmək), /set out/ (yollanmaq), /set up/ (düzəltmək), /sort out/ (aydınlaşdırmaq; həll etmək), /take over/ (bir şeyə nəzarət etmək), /take up/ (cəlb etmək; bir işə maraq göstərmək), /turn up/ (gəlmək; peyda olmaq) and others. Of course, the number of this list can be increased. In different situations, these words, or rather phraseological verbs can have different meanings, which is why they are difficult for learners of English as a second language [Bolinger 1971, s. 71]. 
Among idiomatic verbs, the most idiomatic expressions and words create confusion and difficulty for foreign language learners. Let's look at a few language facts:

1) /My husband said to me that giving up smoking was easy and I must try it// (Həyat yoldaşım mənə dedi ki, siqareti tərgitmək asandır və mən buna cəhd etməliyəm).

2) /Farmers, sailors, and chemists get by perfectly well on the basis of everyday experience, without recourse to Aristotelian logic// (Fermerlər, dənizçilər və kimyaçılar, Aristotelin məntiqinə müraciət etmədən gündəlik təcrübə əsasında mükəmməl şəkildə uğur qazanırlar).

3) /He could not make it out, nor could he trust his own memory// (O, heç nəyi dəqiq xatırlaya bilmirdi, yoxsa o, öz yaddaşınamı inanmalı idi).

\section{CONCLUSION}

Language can be thought of as a system of signs. The cultural value of language as a system of signs was established many years ago. Speakers use language to express themselves and others in different cultural environments. They express their social relations in a language as cultural symbols. For this reason, language is considered to be a means of symbolizing cultural reality.

In the depth study of the relationship between language and culture is not only necessary but also relevant in the teaching and learning of a foreign language. In addition to a foreign language, teachers must teach the culture of that language in their classrooms and culture is inevitable.

In some cases, bilinguals focus on interference in order to speak only one language, which can also be seen as an advantage of bilingualism.

During the influence of bilingualism on the socio-cognitive development of the individual, attention is necessary to be paid to 4 stages: 1) the degree of bilingualism; 2) the function of the bilingualism; 3) the choice of the bilingualism and 4) the interference of it.

One of the advantages of bilingualism is that bilingual children reduce interference between two languages in order to be able to speak one language. Bilingual children are able to respond more quickly to appropriate changes in the situation. Bilinguals are able to more quickly understand the ambiguity or contradiction of the information given to them.

Our conclusion is that while the acquisition of a second language is based on one's innate language learning habits, it also depends on one's explicit and implicit language skills.

Azerbaijani students, who speak English as a second language, are interested in using phraseological combinations, especially idioms, in their conversations. This is partly due to the culture of the Turkic peoples, because Turks prefer to use idiomatic expressions with different emotional shades in their speech and writing because they are emotional.

\section{REFERENCES}

[1] Andrews, E., G. Averyanova and G. Pyadusova. (1997). Russian Verb. Forms and Functions. Moscow: Russky Yazyk Publishers.

[2] Askedal, J. O. (1994). 'Norwegian' in E. König and J. van der Auwera (eds.) Germanic languages. London: Routledge: 219-270.

[3] Bengeleil, N.F. and T.S. Paribakht. (2004). 'L2 Reading Proficiency and Lexical Inferencing by University EFL Learners'. The Canadian Modern Language Review / la revue canadienne des langues vivantes 66 (2): 225-249.

[4] Barnes, M and Eivind Weyhe. (1999). 'Faroese' in E. König and J. van der Auwera (eds.) Germanic languages. London: Routledge: 190-218.

[5] Beebe, L. (1977). 'The influence of the listener on code-switching'. Language Learning 27: 331-339.

[6] Beebe, L. (1980). 'Sociolinguistic variation and style-shifting in second language acquisition'. Language Learning 30: $433-437$.

[7] Bolinger, D. (1971). The phrasal verb in English. Cambridge: Cambridge University Press.

[8] Evtyukhin S. (2003). Incidental Acquisition of English Phrasal verbs by Norwegian and Russian Native Speakers. Ms. University of Troms $\varnothing$.

[9] Gass, S. and L. Selinker. (1983). Language Transfer in Language Learning. Rowley, Mass.: Newbury House.

[10] Huseynov A.R. (2015). A collection of lectures on theoretical grammar of the English language. Baku: Mutarjim.

[11] Kellerman, E. (1987). 'Aspects of transferability in second language acquisition. Chapter 1: Crosslinguistic influence: a review'. Unpublished manuscript, University of Nijmegen.

[12] Kellerman, E. (1987). 'Aspects of transferability in second language acquisition. Chapter 1: Crosslinguistic influence: a review'. Unpublished manuscript, University of Nijmegen.

[13] Odlin, T. (2001). Language Transfer-Cross-Linguistic Influence in Language Learning. Shang Hai: Shang Hai Foreign Language Education Press.

[14] Odlin, T. (2003). 'Cross-linguistic influence' in C. Doughty and M. Long (eds.): The Handbook of Second Language Acquisition. Malden, Mass.: Blackwell.

[15] Sajavaara, K. (1986). Transfer and Second Language Speech Process. New York: Pergamon Press.

[16] Thim, S. (2012). Phrasal Verbs. The English Verb-Particle Construction and Its History. Berlin: Mouton de Gruyer.

[17] Veysalli F.Y. (2013). Basics of linguistics. Baku: Mutarjim.

[18] Veysalli F.Y. (2003). Introduction to German linguistics. Baku: Mutarjim.

[19] Veysalli F.Y. (2015). Cognitive linguistics: basic concepts and perspectives. Baku: Mutarjim.

[20] Wei, Y. Q. \& Li, J. (1998). New Testament. Tian Jin: Tian Jin Peoples Publishing House. 
Sayana Movsum Baghirova was born in Baku. She graduated from the University of Languages. She got her PHD on the dissertation topic titled "Bilingualism and its cognitive aspects" in 2012. She is also expected to get her degree of Doctor of sciences soon. She teaches diplomatic English to BA students of Foreign Languages of International Relations and Management at the Azerbaijan University of Languages.

She got some honors and awards such as Erasmus plus Mundus Scholarship program; Euro Asia Scholarship Program, etc. She got the honor of peace ambassador for active involvement of social inclusion of young families by World Peace Federation, Korea.

Her teaching areas are Linguistics, Psycholinguistics, English as a second language, Psychology.

She got some certificates: The Opportunity of Bilingualism : Serving Today's Young English Language Learners, Harvard Graduate School of Education; CELTA, Cambridge English Language Assessment Part of the University of Cambridge; Norwegian Welfare, International Summer School(University of Oslo), etc.

She speaks some foreign languages: English (fluent), Russian (fluent), Norwegian (intermediate). 